\title{
Helminthological records of six-banded Armadillos Euphractus sexcinctus (Linnaeus, 1758) from the Brazilian semi-arid region, Patos county, Paraíba state, including new morphological data on Trichohelix tuberculata (Parona and Stossich, 1901) Ortlepp, 1922 and proposal of Hadrostrongylus ransomi nov. comb.
}

\author{
Hoppe, EGL. ${ }^{\mathrm{a}, \mathrm{b}^{*}}$, Araújo de Lima, RC. ${ }^{\mathrm{a}}$, Tebaldi, $J H .^{\mathrm{a}}$, Athayde, ACR. ${ }^{\mathrm{c}}$, Nascimento, AA. ${ }^{\mathrm{a}}$ \\ aFaculdade de Ciências Agrárias e Veterinárias - FCAV \\ Universidade Estadual "Júlio de Mesquita Filho" - UNESP, \\ Via de Acesso Prof. Paulo Donato Castellane, s/n, CEP 14887-900, Jaboticabal, SP, Brazil \\ ${ }^{\text {b} C e n t r o ~ U n i v e r s i t a ́ r i o ~ d e ~ R i o ~ P r e t o ~-~ U n i R P, ~}$ \\ Av. Yvette Gabriel Atique, 45, CEP 15025-400, São José do Rio Preto, SP, Brazil \\ ${ }^{c}$ Campus de Patos, Universidade Federal de Campina Grande - UFCG, \\ CP 64, CEP 58700-970 Patos, PB, Brazil \\ *e-mail: e.hoppe@gmail.com
}

Received October 10, 2007 - Accepted February 25, 2008 - Distributed May 31, 2009

(With 16 figures)

\begin{abstract}
This work aimed to evaluate the gastrointestinal helminthfauna composition of six-banded armadillos from the Brazilian semi-arid region. Gastrointestinal contents of six road-killed adult animals from Patos County, Paraíba State, were analyzed. Six species of nematodes, comprising five genera and four families, were recovered from the analyzed animals. New morphological data on Trichohelix tuberculata is given, along with a new taxonomical proposal for Hadrostrongylus ransomi (Travassos, 1935) n. comb. This is the first record for parasitic helminths in this host from the Brazilian semi-arid.
\end{abstract}

Keywords: Caatinga biome, Euphractus sexcinctus, Nematoda, Trichohelix tuberculata, Hadrostrongylus ransomi.

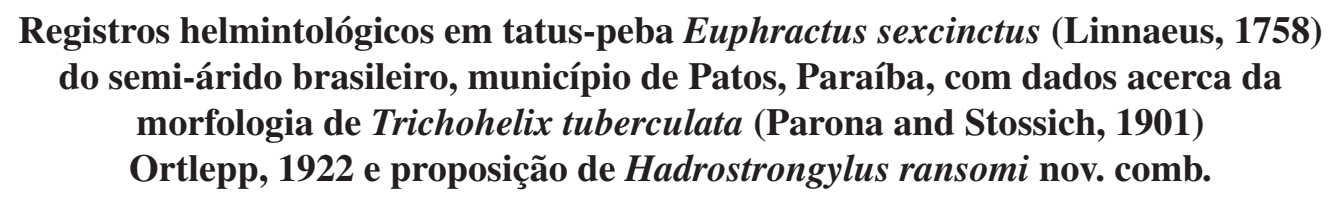

\section{Resumo}

Este trabalho teve como objetivo avaliar a composição da helmintofauna gastrintestinal de tatus-peba da região semiárida brasileira. Conteúdos gastrintestinais de seis animais adultos atropelados nas rodovias do município de Patos, Paraíba, foram analisados. Seis espécies de nematódeos agrupados em cinco gêneros e quatro famílias foram obtidas. Novos dados morfológicos de Trichohelix tuberculata são relatados, e ainda é proposto Hadrostrongylus ransomi (Travassos, 1935) n. comb. Este é o primeiro relato de helmintos parasitas deste hospedeiro no semi-árido brasileiro.

Palavras-chave: Caatinga, Euphractus sexcinctus, Nematoda, Trichohelix tuberculata, Hadrostrongylus ransomi.

\section{Introduction}

Six-banded armadillos Euphractus sexcinctus (Linnaeus, 1758) Wagler, 1830 (Xenarthra Cope, 1889: Dasypodidae Gray, 182) are classified among the subfamily Euphractinae Winge, 1923, along with the genus Chaetophractus Fitzinger, 1871 and closely related to the Tolypeutinae Gray, 1865 (Delsuc, 2002). These ar- madillos are distributed in most of the central and eastern Brazilian territory, Paraguay, Uruguay and northern Argentina. Their occurrence has also been reported in Suriname and east of the Andes, suggesting a wider distribution of this species (Nowak, 1999; Beresca and Cassaro, 2001). 
The six-banded armadillos occur mainly in open areas such as savannahs and scrubs, but they can also inhabit dense forests and jungles (Nowak, 1999). In the Brazilian semi-arid, E. sexcinctus is the armadillo species with the widest area of occurrence, followed by Dasypus novemcinctus Linnaeus, 1758 (Silva et al., 2003). Preferentially herbivorous, E. sexcinctus may scavenge for dead animals and also eat little vertebrates and invertebrates, denoting generalist food habits, in contrast with the more specialist sympatric species $D$. novemcinctus (Bonato, 2002).

Despite the fact that six-banded armadillos are a common species in Brazil and Argentina (Nowak, 1999; Bonato, 2002), little is known regarding the helminthfauna of these animals. This study provides helminthological data along with mean intensity and range of intensity, as well as new morphological data for Trichohelix tuberculata (Parona and Stossich, 1901) Ortlepp, 1922 and a new taxonomical proposal: Hadrostrongylus ransomi n. comb.

\section{Material and Methods}

\subsection{Animals}

From March through September, 2003, six roadkilled armadillos, collected within the Patos County perimeter ( $06^{\circ} 46^{\prime} 19^{\prime \prime} \mathrm{S}$ to $07^{\circ} 38^{\prime} 32^{\prime \prime} \mathrm{S}$ and $36^{\circ} 42^{\prime}$ ' $52^{\prime \prime} \mathrm{W}$ to $\left.38^{\circ} 08^{\prime} 56^{\prime \prime} \mathrm{W}\right)$, Paraíba State, were submitted to the Laboratory of Veterinary Parasitology of Campina Grande Federal University, Health and Rural Technology Center, Patos campus, where they were necropsied. Even though these were animals from road kills, all carcasses were in a good state of preservation. The gastrointestinal contents were washed and sieved and the obtained helminths fixed and conserved in warm Railliet and Henry solution and stored in labelled vials.

After that, the vials were submitted to the Parasitic Diseases Laboratory "Prof. Dr. Orlando Ferrari" of the Department of Preventive Veterinary Medicine and Animal Reproduction, FCAV/Unesp, Jaboticabal, São Paulo state, for taxonomic identification.

\subsection{Study area}

The Brazilian semi-arid is an area of about $800,000 \mathrm{~km}^{2}$, spread over ten States, mainly in the Northeastern region of the country. The pronounced environmental heterogeneity, allied with the uniqueness of certain ecotopes, may contribute to a great richness of the invertebrate fauna (Silva et al., 2003).

In Patos County (Figure 1), the temperature ranges from 24 to $28{ }^{\circ} \mathrm{C}$, with an average pluviometric index of $681.6 \mathrm{~mm}$ (Costa Silva et al., 2003). There is a predominance of the hyperxerophyle Caatinga scrub vegetation, due to the elevated hydric deficiency over the year. The physiographic area is close to Serra de Santa Luzia, a Caatinga prioritary area for invertebrate conservation, because of its richness of species (Silva et al., 2003).

\subsection{Parasitological methods}

For morphological studies, the helminths were clarified in $80 \%$ acetic acid and beechwood creosote. Measurements of morphological characters, expressed in millimetres, were taken from ten mature nematodes of each sex and were expressed as range followed by sample mean and coefficient of variation in parenthesis. Synlophe studies were conducted when needed and were done according to the technique described by DuretteDesset (1969). Drawings were made with a camera lucida attached to a Carl-Zeiss ${ }^{\circledR}$ microscope. After total
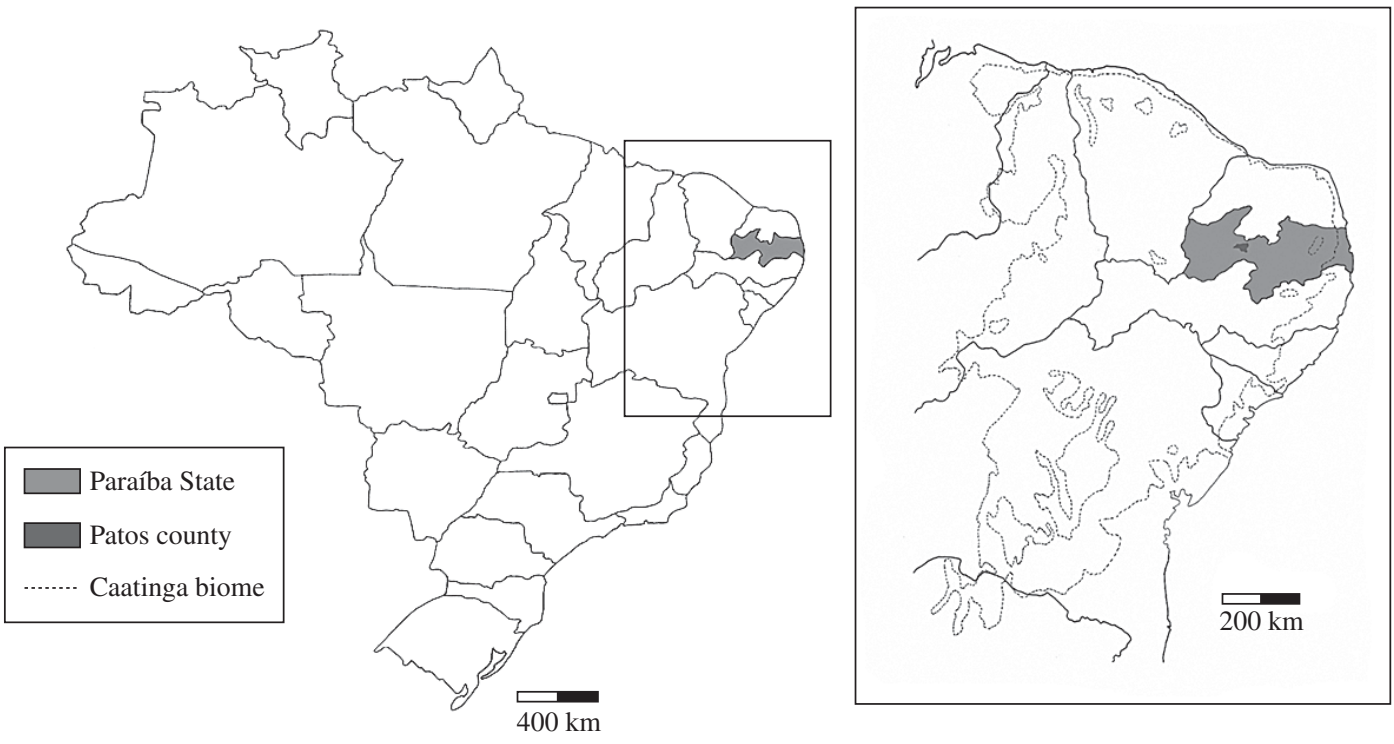

Figure 1. Schematic map representing the study area and the Caatinga Biome range (Adapted from: Silva et al., 2003). 
counts were made, mean intensity and range of intensity were determined, based on Bush et al. (1997).

Taxonomic identification was based on reports of the following authors: Travassos (1937), Durette-Desset (1983), Navone (1987), Santos et al. (1990), Vicente et al. (1997), and Hoppe and Nascimento (2007). Paratypes were deposited in the Helminthological Collection of the Oswaldo Cruz Institute Foundation (CHIOC), Rio de Janeiro, Rio de Janeiro state, Brazil and also in the Laboratory of Animal Parasitic Diseases "Prof. Dr. Orlando Ferrari" helminthologic collection, Department of Preventive Veterinary Medicine and Animal Reproduction, FCAV/Unesp, Jaboticabal County, São Paulo state, Brazil.

\section{Results and Discussion}

All studied armadillos were parasitized by two nematode species at least, whilst cestodes, trematodes, and acanthocephalans were not observed. Five nematodes, comprising four genera and three families were diagnosed (Table 1). Among these, new morphological and taxonomical data were obtained for two nematode species, Trichohelix tuberculata (Parona and Stossich, 1901) Ortlepp, 1922 and Hadrostrongylus ransomi (Travassos, 1935) n. comb.

Trichohelicinae (Travassos, 1937) descr. emend.

Diagnosis: Trichostrongyloidea Cram, 1927, Molineidae Durette-Desset and Chabaud, 1977. Spiraled nematodes with striated cephalic dilatation. Didelphic, prodelphic females with vulvar opening close to anus. Short vagina vera and ovejector. Males with ample, trilobed copulatory bursa. Large dorsal lobe, with dorsal ray strongly developed. Very long, thin, pre-bursal papillae. Equal spicules, and gubernacule present. Synlophe pattern is variable according to body portion, formed by asymmetrical ridges with ventral-dorsal orientation.
Type genus: Trichohelix Ortlepp, 1922

Remarks: Durette-Desset (1983), in an attempt of the organization of the Molineidae Durette-Desset and Chabaud, 1977 family mainly according to their synlophe pattern and female reproductive system, allocated the single-specific genus Trichohelix Ortlepp, 1922 along the Anoplostrongylinae Chandler, 1938. However, data obtained in this study permit us to reconsider the taxonomical positioning of this taxon in the subfamily Trichohelicinae Travassos, 1935, due to its unique synlophe pattern and female reproductive system morphology, representing an autapomorphy not observed in other Anoplostrongylinae species.

\section{Trichohelix Ortlepp, 1922}

\section{Trichohelix tuberculata}

\section{(Parona and Stossich, 1901) Ortlepp, 1922}

Diagnosis: Strongly spiraled nematodes with striated cephalic dilatation, reddish in color in situ. Cuticle has inflations seen in all body length. Filariform esophagus, slightly thicker on distal third. Nervous ring situated on the middle part of the esophagus and the excretory pore opening is next to the esophageal-intestinal junction. Cervical papillae are absent (Figure 2).

The synlophe is formed by many ridges asymmetrically disposed with variable size. The ventral face of the nematode body has three to four striated ventral longitudinal ridges, depending on the sectioned body region (Figures 3 and 4).

Males: Body length $3.2592 \quad$ - 3.7592 (3.5401 \pm 0.2531$)$, width at esophagus-intestinal junction $0.0651-0.079(0.0697 \pm 0.0058)$. Cephalic vesicle finely striated, $0.0465-0.0558(0.0534 \pm 0.0044)$ long. Short esophagus, measuring $0.293-0.3674(0.3325 \pm 0.0348)$ long; thickened next to esophageal-intestinal junction. Nerve ring located in the mid-esophagean region,

Table 1. Intestinal helminths of six free-ranging road-killed Euphractus sexcinctus from Patos county region, Paraíba state, Brazil.

\begin{tabular}{|c|c|c|c|}
\hline $\begin{array}{c}\text { Helminth species } \\
(\text { CHIOC access number })\end{array}$ & Habitat & $\begin{array}{c}\text { Mean } \\
\text { Intensity }\end{array}$ & $\begin{array}{l}\text { Range of } \\
\text { Intensity }\end{array}$ \\
\hline \multicolumn{4}{|l|}{ ANCYLOSTOMATOIDEA Looss, 1905} \\
\hline \multicolumn{4}{|l|}{ Ancylostomatidae Nicoll, 1927} \\
\hline Ancylostoma caninum (Ercolani, 1859) (CHIOC 35524) & SI & 3.00 & $-*$ \\
\hline \multicolumn{4}{|l|}{ TRICHOSTRONGYLOIDEA Cram, 1927} \\
\hline \multicolumn{4}{|l|}{ Molineidae Durette-Desset and Chabaud, 1977} \\
\hline Trichohelix tuberculata (Parona \& Stossich, 1901) (CHIOC 35525) & SI & 37.50 & $6-66$ \\
\hline Hadrostrongylus ransomi (Travassos, 1935) n. comb. (CHIOC 35526) & SI & 107.00 & $30-240$ \\
\hline \multicolumn{4}{|l|}{ HETERAKOIDEA Chabaud, 1957} \\
\hline \multicolumn{4}{|l|}{ Aspidoderidae Skrjabin and Schikhobalova, 1947} \\
\hline Aspidodera fasciata (Schneider, 1866) (CHIOC 35527) & LI & 64.33 & $1-113$ \\
\hline Aspidodera scoleciformis (Diesing, 1935) (CHIOC 35528) & LI & 68.33 & $52-84$ \\
\hline
\end{tabular}

SI - Small intestine; LI - Large intestine ; * not observed. 


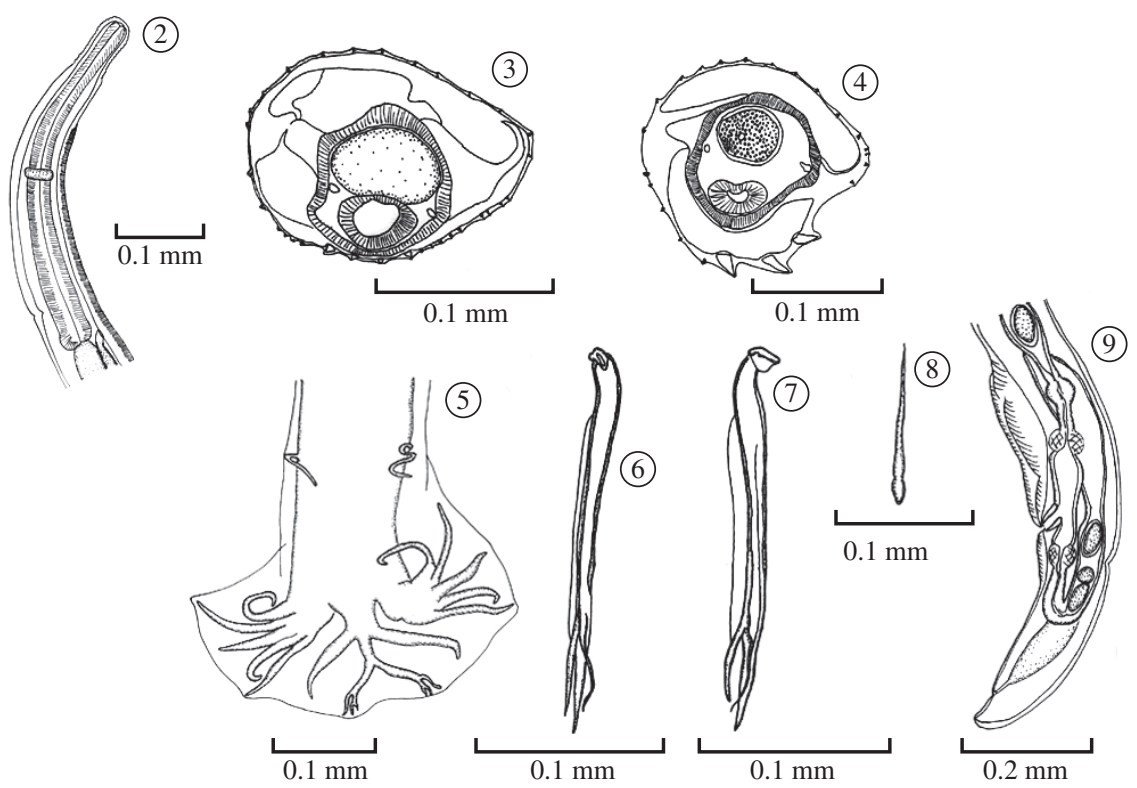

Figures 2-9. Trichohelix tuberculata: 2) Anterior portion, lateral view; 3) Synlophe, esophageal portion transversal cut; 4) Synlophe, mid-body transversal cut; 5) Copulatory bursa, ventral view; 6) Left spicule, ventral view; 7) left spicule, lateral view; 8) Gubernacule, ventral view; and 9) Female vulvar region and tail tip.
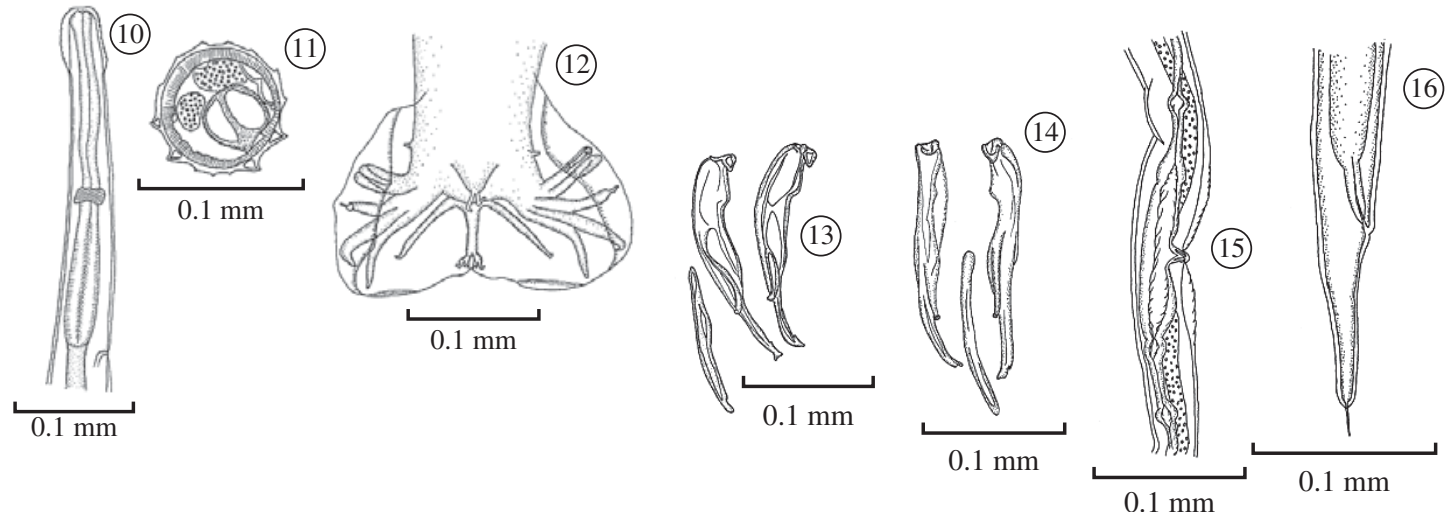

Figures 10-16. Hadrostrongylus ransomi: 10) Anterior portion, lateral view; 11) Synlophe, mid-body transversal cut; 12) Copulatory bursa, ventral view; 13) Spicules and gubernacule, lateral view; 14) Spicules and gubernacule, ventral view; 15) Female vulvar region, lateral view; and 16) Female tail tip.

and excretory pore next to esophagus ending, distant $0.1488-0.172(0.1627 \pm 0.0122)$, and $0.2558-0,3209$ $(0.2790 \pm 0.0294)$ from anterior ending, respectively. Ample, trilobed copulatory bursa (Figure 5), with lateral and dorsal lobes well developed. The pre-bursal papillae are long and thin. Bursal pattern type 2-1-2. Rays 2 and 3 originate from common trunk and diverge since the base. The former bends toward its base and the latter is slightly curved, reaching the bursal margin. Rays 4, 5 and 6 originate from a common trunk, as well. The ray 4 is shorter and thicker than rays 5 and 6 , which are longer and thinner. Ray 5 bends toward ray 6 . The common dorsal ray trunk is short and thick, from which originate the external-dorsal and dorsal rays. The latter is split in two symmetrical, trifurcated branches.
Spicules are symmetrical (Figures 6 and 7), with a smooth spicular membrane originated on proximal third and extended to the distal extremity, measuring $0.1627-0.1767(0.1743 \pm 0.00659)$ long. The spicules are trifurcated on distal extremity, being two straight and sharp points and one thin and curved point. Gubernacule (Figure 8) is simple, with proximal ending sharpened and a rounded distal tip, measuring $0.0837-0.1023$ $(0.0999 \pm 0.0088)$.

Females: Body length 5.1481 - 5.6296 (5.2407 \pm 0.1958); width at esophageal ending $0.0790-0.1000(0.0837 \pm 0.0080)$. Cephalic vesicle is similar to males, $0.0511-0.0727(0.0604 \pm 0.0083)$. Esophagus is short, thicker on the base, measuring $0.3767-0.4454(0.4093 \pm 0.0244)$ long. Nerve ring and 
excretory pore situated $0.1720-0.2046(0.1720 \pm 0.0156)$ and $0.3441-0.3767(0.3627 \pm 0.0129)$ distant from anterior ending, respectively.

They are didelphic and prodelphic, with vulvar opening close to anus (Figure 9), located $0.2744-0.3518$ $(0.3090 \pm 0.0299)$ and $0.0454-0.074(0.0511 \pm 0.0109)$ from tail tip, respectively. Cranially to the vulvar opening there is a strongly striated cuticular dilatation. The posterior branch of the reproductive tract, shorter than the anterior branch, is curved after the vagina vera sphincter, bending cranially towards the anterior body ending. The rounded-tipped tail of the females is abruptly tapered. Eggs are ellipsoid, smooth-shelled and non-morulated in utero.

Host: Euphractus sexcinctus (Linnaeus, 1758).

Other hosts: Chaetophractus villosus (Desmarest, 1804), Cabassous unicinctus (Linnaeus, 1758).

Habitat: Small intestine.

New locality record: Patos County, Paraíba State, Brazil.

Types: One male and one female (Paratypes) are deposited under Collection number CHIOC 35525, as wet mounts.

Remarks: Previous synlophe studies of T. tuberculata (Navone, 1987) showed absence of crests. However, this author used paraffin-embedded histological sections that may have lead to misinterpretation.

This species shows tendency to host specificity, as previous studies only recorded its occurrence in Tolypeutinae and Euphractinae armadillos, despite one report in Conepatus suffocans (Illiger, 1811) (Carnivora Bowdich, 1821: Mephitidae Bonaparte, 1845) (Travassos, $1937)$ that is probably due to pseudoparasitism. There are reports of this nematode parasitizing E. sexcinctus from the Brazilian Pantanal wetlands, Mato Grosso do Sul State (Hoppe et al., 2006).

\section{Hadrostrongylus ransomi nov. comb.}

Diagnosis: Trichostrongyloidea Cram, 1927, Molineidae Durette-Desst and Chabaud, 1977, Anoplostrongylinae Chandler, 1938. Slender, non-spiraled nematodes, with finely striated cephalic vesicle. Cervical papillae are absent. Short, claviform esophagus, thickened next to the base. Nerve ring on mid-body of esophagus, while the excretory pore opening situates after the esophageal-intestinal junction (Figure 10). Synlophe on mid-body section is formed by four main ventral crests and ten secondary smaller crests all over the nematode body (Figure 11), with ventral-dorsal orientation. Males with bilobed copulatory bursa, strongly attached to ventral body surface, with bursal rays type 2-1-2. Small pre-bursal papillae present. Rays 2 and 3 originate from common trunk and diverge next to distal third part, reaching the bursal margin. Rays 4, 5 and 6 share the same trunk, diverging on their proximal third part. The short, fine-tipped, ray 4 does not reach the bursal margin. Externo-dorsal rays rises next to body insertion of common dorsal trunk, and the dorsal ray is symmetrical, bifurcated in two branches, which are trifurcated (Figure 12). Strongly chitinised subequal spicules and gubernacule present (Figures 13 and 14). Females are didelphic, amphidelphic tending to prodelphy, and have vulvar opening (Figure 15) situated on distal third part of the body. Eggs are elliptical, smoothshelled, and non-moruled in utero. The tail has a terminal spine (Figure 16).

Males: Body length 4.1764 - 5.5882 $(5.0156 \pm 0.5037)$, width at esophageal-intestinal junction $0.0511-0.0790(0.0576 \pm 0.0083)$. Cephalic vesicle is $0.0571-0.0952(0.0771 \pm 0.0114)$ long. Esophagus $0.3142-0.4000(0.3514 \pm 0.0252)$ long, with nerve ring situated on its mid part, $0.1714-0.2380$ $(0.2009 \pm 0.0226)$ from anterior ending. Excretory pore located after the esophagus-intestinal junction, $0.3238-0.4095(0.3671 \pm 0.0229)$ from cranial part. Spicules subequal in shape, but similar in length, measuring $0.1441-0.1813(0.1604 \pm 0.0101)$. Gubernacule measures $0.0930-0.1302(0.1065 \pm 0.0127)$ in length.

Females: Body length 4.8823 - 6.2941 $(5.8235 \pm 0.4573)$, width at esophageal-intestinal junction $0.0558-0.0744(0.0623 \pm 0.0059)$. Cephalic dilatation $0.0571-0.1142(0.0762 \pm 0.0155)$. Esophagus thickened on distal ending, $0.3142-0.4190(0.3523 \pm 0.0324)$. Nerve ring and excretory pore opening situated 0.1904 $-0.2666(0.2057 \pm 0.0247)$ and $0.3428-0.4380$ $(0.3728 \pm 0.0291)$ from anterior ending, respectively. Also, as seen in males, female excretory pore opening is located after the esophageal ending. Vulvar and anal opening are $0.9629-1.3529(1.1558 \pm 0.1146)$ and $0.0790-0.1666(0.1012 \pm 0.0252)$ distant from tail tip, respectively.

Host: Euphractus sexcinctus (Linnaeus, 1758)

Other hosts: Cabassous unicinctus (Linnaeus, 1758) and Dasypus novemcinctus Linnaeus, 1758.

Habitat: Small intestine

Locality: Patos County, Paraíba State, Brazil.

Synonyms: Delicata ransomi Travassos, 1935.

Types: One male and one female (Paratypes) are deposited under Collection number CHIOC 35526, as wet mounts.

Remarks: Travassos (1937) describes this species as parasite of $C$. unicinctus and D. novemcinctus from Rio de Janeiro state, Brazil. However, the author mentions that some morphological characteristics set this species apart of other congeneric species, suggesting that a better taxonomical replacement should be done. Hoppe and Nascimento (2007), based on a nematode species found parasitizing large intestine of $D$. novemcinctus from the Brazilian Pantanal wetlands, erect the genus Hadrostrongylus and describe $H$. speciosum, also found parasitizing E. sexcinctus from the same physiographic region (Hoppe et al., 2006). Until now, there are no reports of co-parasitism by $H$. speciosum and $H$. ransomi, suggesting that these congeneric species could not be two morphotypes of a single polymorphic species. H. ransomi may be easily differentiated from 
$H$. speciosum by its symmetrical dorsal ray, equal-sized spicules and secondary synlophean structures.

\section{Further Considerations}

Contrary to previous observations regarding E. sexcinctus helminthfauna by Lombardero and Moriena (1977), and Fujita et al. (1995), no gastric helminths have been observed in this work. Those authors' studies were based on specimens collected from physiographic areas much different from that of the present work, which is hotter and drier than theirs. This fact may also explain the minor diversity of the obtained helminth species. The species diversity is also inferior to that observed in D. novemcinctus from the Brazilian Pantanal wetlands (Hoppe and Nascimento, 2007), and Aspidodera fasciata (Schneider, 1866) is the only species diagnosed in both Biomes.

Ancylostoma caninum (Ercolani, 1859) infection observed in one armadillo may be due cross infection with infective forms originated from sympatric carnivores, as only three nematodes have been found in one host. Despite the great resemblance of $A$. caninum with the armadillo ancylostome Ancylostoma martinagliai Mönnig, 1931 (Santa-Cruz et al., 1997), these species can be separated by the buccal capsule morphology, discarding any possibilities of misdiagnosis.

This study is the first record for parasitic helminths in E. sexcinctus from Paraíba state, representing a new locality report for these species, as well as new host records for $H$. ransomi, previously found on Brazilian $D$. novemcinctus and C. unicinctus, according to Vicente et al. (1997), contributing to a better knowledge of the Caatinga biodiversity.

\section{References}

BERESCA, AM. and CASSARO, K., 2001. Biology and captivity management of armadillos and anteaters. In FOWLER, ME. and CUBAS, ZS. (Eds.). Biology, Medicine and Surgery of South American Wild Animals. Ames: Iowa State University Press. p. 238-255.

BONATO, V., 2002. Ecologia e história natural de Tatus do Cerrado de Itirapina, São Paulo (Xenarthra: Dasypodidae). Campinas: Universidade de Campinas. 91 p. Dissertação de Mestrado.

BUSH, AO., LAFFERTY, KD., LOTZ, JM. and SHOSTAK, AW., 1997. Parasitology meets ecology on its own terms: Margolis et al. revisited. Journal of Parasitology, vol. 83, no. 4, p. $575-583$.

COSTA-SILVA, GM., SILVA, H., CAVALCANTI, MLF. and MARTINS, PL., 2003. Autecologia de Bauhinia forficata L.: espécie ameaçada de extinção no ecossistema da Caatinga. Revista de Biologia e Ciências da Terra, vol. 3, no. 2, p. 1-15.

DELSUC, F., 2002. Phylogénie moléculaire des Xénarthres (tatous, fourmiliers et paresseux): application des méthodes probabilistes à la reconstruction de leur histoire évolutive au sein des Mammifères placentaires. Montpelier: Université Montpellier II. 155p. Tese de Doutorado.
DURETTE-DESSET, MC., 1969. Les systèmes d'arêtes cuticulaires chez les Nématodes Héligmosomes parasites de Muridés australiens. Annales de Parasitologie Humaine et Comparée, vol. 44, p. 733-747.

1983. Keys to the Genera of the Superfamily Trichostrongyloidea. In ANDERSON, RC., CHABAUD, AG. and WILMOTT, S. (Eds.). CIH keys to the nematode parasites of vertebrates. Farnham Royal: Commonwealth Agricultural Bureaux. $86 \mathrm{p}$.

FUJITA, O., ABE, N., OKU, Y., SANABRIA, L., INCHAUSTTI, A. and KAMIYA, M., 1995. Nematodes of armadillos in Paraguay: a description of a new species Aspidodera esperanzae (Nematoda: Aspidoderidae). Journal of Parasitology, vol. 81, no. 6 , p. 936-941.

HOPPE, EGL. and NASCIMENTO, AA., 2007. Natural infection of gastrointestinal nematodes in long-nosed armadillos Dasypus novemcinctus Linnaeus, 1758 from Pantanal wetlands, Aquidauana sub-region, Mato Grosso do Sul State, with the description of Hadrostrongylus speciosum n. gen. et n. sp. (Molineidae: Anoplostrongylinae). Veterinary Parasitolology, vol. 144 , no. 1-2, p. 87-92.

HOPPE, EGL., PEREIRA, LM., SOUTO, LSC., TEBALDI, JH. and NASCIMENTO, AA., 2006. Nematódeos gastrintestinais de tatus-peba Euphractus sexcinctus (Linnaeus, 1758) provenientes do Pantanal Sul-Matogrossense, sub-região de Aquidauana, com registro de novo hospedeiro para Hadrostrongylus speciosum (Hoppe and Nascimento, 2006). Biologico, vol. 68, no. 2, p. 29-321.

LOMBARDERO, J. and MORIENA, RA., 1977. Mazzia mazzia Khalil and Vogelsang, 1932, en dasipodidos de la Argentina (redescripción). Revista de Medicina Veterinária, vol. 58, no. 2, p. $141-142$

NAVONE, GT., 1987. Estudios Parasitologicos en Edentados Argentinos. III. Nematodes Trichostrongylidos, Macielia elongata sp. nov.; Moennigia virilis sp. nov. y Trichohelix tuberculata (Parona y Stossich, 1901) Ortlepp, 1922 (Molineidae - Anoplostrongylinae) Parasitos de Chaetophractus villosus Desmarest y Tolypeutes matacus (Desmarest) (Xenarthra Dasypodidae). Neotropica, vol. 33, no. 90, p. 105-117.

NOWAK, RM., 1999. Walker's mammals of the world. Baltimore: The Johns Hopkins University Press. p. 451-469.

SANTA-CRUZ, AM., ROTT, MIO., RESOAGLI, EH. and MARTÍNEZ, FA., 1997. Chaetophractus vallerosus (Edentata: Dasypodidae), a New Host for Ancylostoma martinagliai Mönnig, 1931 in Argentina. Revista de Medicina Veterinária, vol. 78 , no. 6 , p. $388-391$

SANTOS, CP., LENT, H. and GOMES, DC., 1990. The Genus Aspidodera Railliet and Henry, 1912 (Nematoda: Heterakoidea): revision, New Synonyms and key for species. Revista Brasileira de Biologia = Brazilian Journal of Biology, vol. 50, no. 4, p. 1017-1031.

SILVA, JMC., TABARELLI, M., FONSECA, MT. and LINS, LV., 2003. Biodiversidade da Caatinga: áreas e ações prioritárias para a conservação. Brasília: Ministério do Meio Ambiente. p. 1-382.

TRAVASSOS, L., 1937. Revisão da Família Trichostrongylidae Leiper, 1912. Rio de Janeiro: Instituto Oswaldo Cruz. 807 p.

VICENTE, JJ., RODRIGUES, HO., GOMES, DC. and PINTO, RM., 1997. Nematóides do Brasil. Parte V: Nematóides de mamíferos. Revista Brasileira de Biologia = Brazilian Journal of Biology, vol. 14, no. 1, 452 p. 